\section{Groundwater Quality in the Cascade Range and Modoc Plateau, California}

Groundwater provides more than 40 percent of California's drinking water. To protect this vital resource, the State of California created the Groundwater Ambient Monitoring and Assessment (GAMA) Program. The Priority Basin Project of the GAMA Program provides a comprehensive assessment of the State's groundwater quality and increases public access to groundwater-quality information. The Cascade Range and Modoc Plateau area constitutes one of the study units being evaluated.

\section{The Cascade Range and Modoc Plateau Study Unit}

The Cascade Range and Modoc Plateau (CAMP) study unit covers approximately 15,000 square miles in northeastern California. The study unit was divided into six study areas on the basis of geologic features: Eastside Sacramento Valley, Honey Lake Valley, Cascade Range and Modoc Plateau Low-Use Basins, Quaternary Volcanic Areas, Shasta Valley and Mount Shasta Volcanic Area, and Tertiary Volcanic Areas (Shelton and others, 2013; Fram and Shelton, 2015).

The volcanic rocks of the CAMP study unit can be highly productive aquifers. Groundwater resides in porous zones between lava flows, fractures that formed during cooling of the lavas, lava tubes, and other features. These systems can be interconnected or isolated, resulting in variability in water levels, well yields, and water quality on local and regional scales. Sedimentary groundwater basins in the CAMP study unit primarily contain Quaternary-age alluvial fan, fluvial, and lake sediments (California Department of Water Resources, 2003). Aquifers composed of different materials can contain groundwater with different chemical compositions.

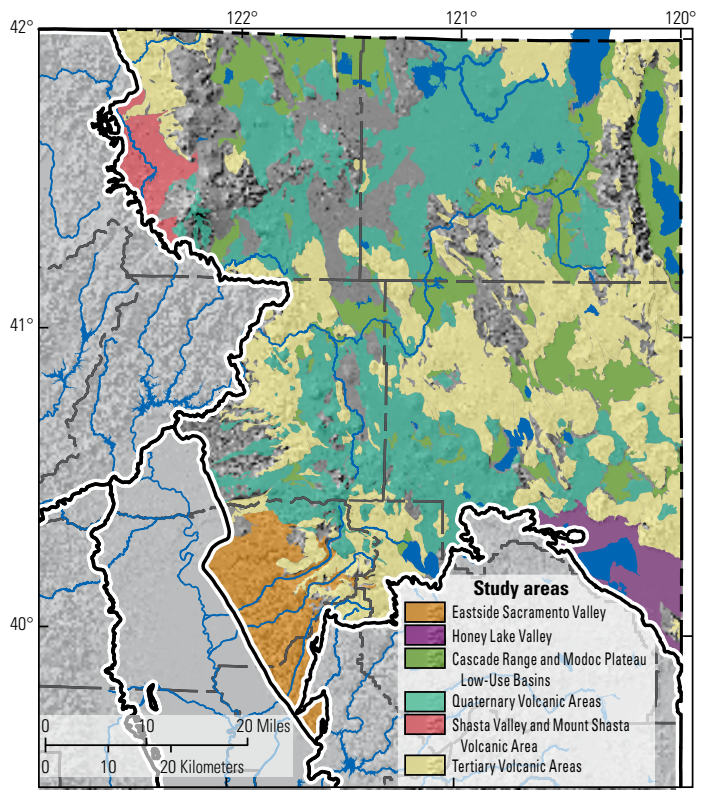

The primary aquifer system of the CAMP study unit is defined as those parts of the aquifer system tapped by wells and springs listed in the State of California's database of public drinking-water supply sources. In the CAMP study unit, about 10 percent of these sources are springs. Of those that are wells, most are drilled to depths of 140 to 400 feet, consist of solid casing or a seal from the land surface to a depth of about 50 to 220 feet, and are open or have perforated casing below that depth. Water quality in the primary aquifer system can differ from that in the shallower and deeper parts of the aquifer system.

Average annual precipitation ranges from 10 to 20 inches over much of the area to over 80 inches at high elevations in Lassen Volcanic

National Park and on Mount Shasta. The study unit includes three major hydrologic regions: the Klamath River watershed, the Sacramento River watershed, and closed drainage basins of the North Lahonton area. About 80 percent of the land in the study unit is natural, and much of that land is in national forests. About 16 percent of the land is used for agriculture, and about 4 percent is urbanized.

Recharge to CAMP study unit aquifers is mainly from stream-channel infiltration, direct infiltration of precipitation and snow melt, flow through volcanic features, and in some areas, infiltration of irrigation water. Groundwater exits the aquifer system when it is pumped for irrigation or drinking-water supply, discharges into springs, streams and lakes, or evaporates from areas with a shallow depth to groundwater.
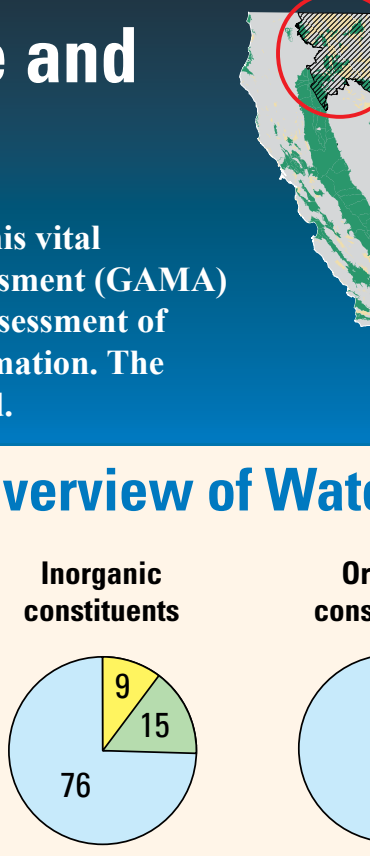

\section{CONSTITUENT CONCENTRATIONS}

$\bigcirc$ High $\bigcirc$ Moderate $\bigcirc$ Low or not detected

Pie charts illustrate the percentage of the primary aquifer system, on an areal basis, with concentrations in the three specified categories.

GAMA’s Priority Basin Project evaluates the quality of untreated groundwater. However, for context, concentrations measured in groundwater are compared to benchmarks established for drinking-water quality, such as maximum contaminant levels (MCL). A concentration above a benchmark is defined as high. Benchmarks and definitions of moderate and low concentrations are discussed in the inset box on page 3 .

Many inorganic constituents occur naturally in groundwater. The concentrations of the inorganic constituents can be affected by natural processes as well as by human activities. In the CAMP study unit, one or more inorganic constituents were present at high concentrations in about 9 percent of the primary aquifer system and at moderate concentrations in about 15 percent.

Human-made organic constituents are found in products used in the home, business, industry, and agriculture. Organic constituents can enter the environment through normal usage, spills, or improper disposal. In this study unit, organic constituents were not present at high or moderate concentrations in the primary aquifer system. 


\section{INORGANIC CONSTITUENTS}
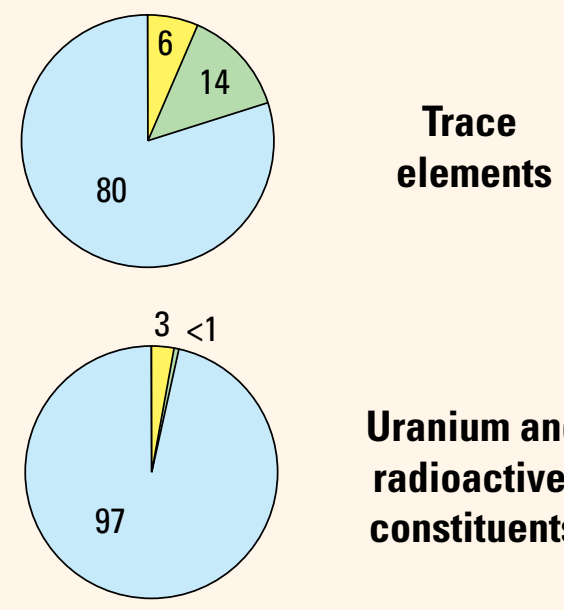

\section{Uranium and radioactive constituents}

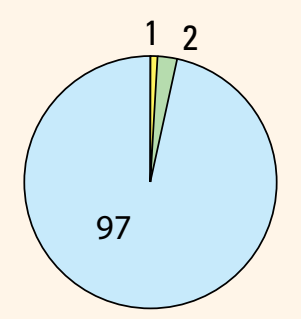

Nutrients

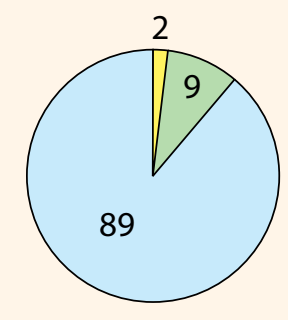

\section{Total dissolved solids}

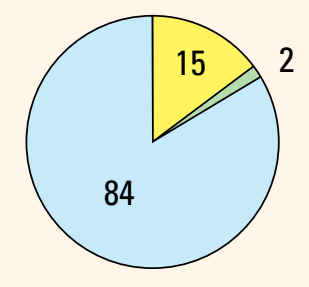

Manganese and/or iron

\section{SPECIAL-INTEREST CONSTITUENT}

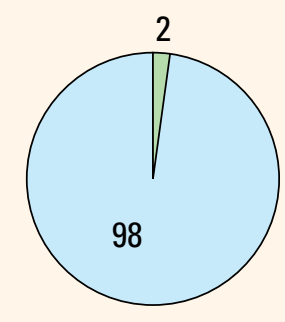

\section{Inorganic Constituents with Human-Health Benchmarks}

Trace elements are naturally present in the minerals of rocks and sediments and in the water that comes into contact with those materials. In the CAMP study unit, trace elements were detected at high concentrations in about 6 percent of the primary aquifer system and at moderate concentrations in about 14 percent. Arsenic, boron, molybdenum, and vanadium were the trace elements that most frequently occurred at high and moderate concentrations.

Radioactivity is the release of energy or energetic particles during spontaneous decay of unstable atoms. Humans are exposed to small amounts of natural radioactivity every day. Most of the radioactivity in groundwater comes from the decay of naturally occurring isotopes of uranium and thorium in minerals in aquifer materials. Radioactive constituents occurred at high levels in about 3 percent of the primary aquifer system and at moderate levels in less than 1 percent. Uranium was the constituent that most frequently occurred at high levels.

Nutrients are naturally present at low concentrations in groundwater, and high and moderate concentrations generally occur as a result of human activities. Common sources of nutrients include fertilizer applied to crops and landscaping, seepage from septic systems, and human and animal waste. Nutrients were present at high concentrations in about 1 percent of the primary aquifers and at moderate concentrations in about 2 percent. Nitrate was the only nutrient detected at high concentrations.

\section{Inorganic Constituents with Non-Health Benchmarks}

(Not included in water-quality overview charts shown on the front page)

Some constituents affect the aesthetic properties of water, such as taste, color, and odor, or can create nuisance problems, such as staining and scaling. The benchmarks used for these constituents were non-regulatory secondary maximum contaminant level benchmarks.

Total dissolved solids (TDS) concentration is a measure of the salinity of the groundwater, and all water naturally contains TDS as a result of the weathering and dissolution of minerals in rocks and sediments. The State of California has a recommended and an upper limit for TDS in drinking water. TDS concentrations were high (greater than the upper limit) in about 2 percent of the primary aquifer system and moderate (between the recommended and upper limits) in about 9 percent.

Anoxic conditions in groundwater (low amounts of dissolved oxygen) can result in release of naturally occurring manganese and iron from minerals into groundwater. Manganese or iron was present at high concentrations in about 15 percent of the primary aquifer system and at moderate concentrations in about 2 percent.

\section{Special-Interest Constituent: Perchlorate}

(Not included in water-quality overview charts shown on the front page)

Perchlorate is an inorganic constituent that has been regulated in California drinking water since 2007. It is used in solid rocket fuel, fireworks, safety flares, and other products, is present in some fertilizers, and occurs naturally at low concentrations in groundwater. Perchlorate was not detected at high concentrations and was detected at moderate concentrations in about 2 percent of the primary aquifer system. 


\section{RESULTS: Groundwater Quality in the Cascade Range and Modoc Plateau}

\section{ORGANIC CONSTITUENTS}

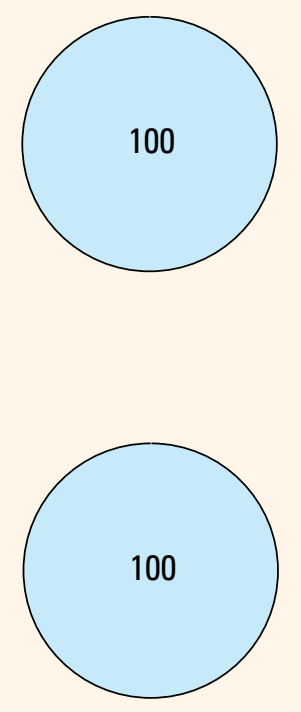

\section{Organic Constituents}

The Priority Basin Project uses laboratory methods that can detect low concentra-

VOCs tions of volatile organic compounds (VOCs) and pesticides, far below human-health benchmarks. VOCs and pesticides detected at these very low concentrations can be used to help trace water from the landscape into the aquifer system.

\section{Volatile Organic Compounds with Human-Health Benchmarks}

VOCs are present in many household, commercial, industrial, and agricultural products and are characterized by their tendency to volatilize (evaporate) into the air. In the CAMP study unit, VOCs were not detected at high or moderate concentrations in the primary aquifer system.

\section{Pesticides Pesticides with Human-Health Benchmarks}

Pesticides, including herbicides, insecticides, and fumigants, are applied to crops, gardens, lawns, around buildings, and along roads to help control unwanted vegetation (weeds), insects, fungi, and other pests. In the CAMP study unit, pesticides were not detected at high or moderate concentrations in the primary aquifer system.

\section{BENCHMARKS FOR EVALUATING GROUNDWATER OUALITY}

GAMA's Priority Basin Project uses benchmarks established for drinking water to provide context for evaluating the quality of untreated groundwater. After withdrawal, groundwater may be disinfected, filtered, mixed, and exposed to the atmosphere before being delivered to consumers. Federal and California regulatory benchmarks for protecting human health (Maximum Contaminant Level, MCL) are used when available. Otherwise, nonregulatory benchmarks for protecting aesthetic properties, such as taste and odor (Secondary Maximum Contaminant Level, SMCL), and nonregulatory benchmarks for protecting human health (Notification Level, NL, and Lifetime Health Advisory, HAL) are used.

\section{PERCENTAGE OF STUDY AREA}

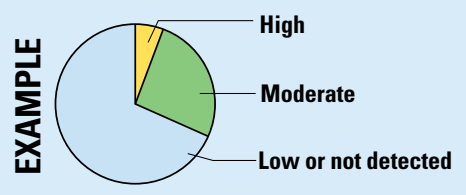

Values are a percentage of the area of the primary aquifer system with concentrations in the three specified categories.

\section{High, moderate, and low concentrations are defined relative to benchmarks}

Concentrations are considered high if they are greater than a benchmark. For inorganic constituents, concentrations are moderate if they are greater than one-half of a benchmark. For organic and special-interest constituents, concentrations are moderate if they are greater than one-tenth of a benchmark; this lower threshold was used because organic constituents are generally less prevalent and have smaller concentrations relative to benchmarks than inorganic constituents. Low concentrations include non-detections and values less than moderate concentrations. Methods for evaluating water quality are discussed by Fram and Shelton (2015).

\section{Benchmark type and value for selected constituents.}

[Benchmark types: California, State Water Resources Control Board Division of Drinking Water; Federal, U.S. Environmental Protection Agency; HAL, lifetime health advisory; MCL, maximum contaminant level; NL, notification level; SMCL, secondary maximum contaminant level. Abbreviations: ppb, parts per billion or micrograms per liter $(\mu \mathrm{g} / \mathrm{L})$; ppm, parts per million or milligrams per liter $(\mathrm{mg} / \mathrm{L})$ ]

\begin{tabular}{|c|c|c|c|c|c|}
\hline \multirow{2}{*}{ Constituent } & \multicolumn{2}{|c|}{ Benchmark } & \multirow{2}{*}{ Constituent } & \multicolumn{2}{|c|}{ Benchmark } \\
\hline & Type & Value & & Type & Value \\
\hline Arsenic & Federal MCL & $10 \mathrm{ppb}$ & Nitrate, as nitrate & Federal MCL & $45 \mathrm{ppm}$ \\
\hline Boron & California NL & $1 \mathrm{ppm}$ & $\begin{array}{l}\text { Total dissolved solids } \\
\quad \text { (TDS) }\end{array}$ & California SMCL & $1,000 \mathrm{ppm}$ \\
\hline Molybdenum & Federal HAL & $40 \mathrm{ppb}$ & Iron & California SMCL & $300 \mathrm{ppb}$ \\
\hline Vanadium & California NL & $50 \mathrm{ppb}$ & Manganese & California SMCL & $50 \mathrm{ppb}$ \\
\hline Uranium & Federal MCL & $30 \mathrm{ppb}$ & Perchlorate & California MCL & $6 \mathrm{ppb}$ \\
\hline
\end{tabular}




\section{Factors that Affect Groundwater Quality}

Inorganic constituents with health-based benchmarks were present at high or moderate concentrations in 24 percent of the primary aquifer system of the CAMP study unit; however, the proportions ranged from a low of 9 percent in the Eastside Sacramento Valley study area to a high of 64 percent in the Honey Lake Valley study area. In addition, the individual constituents present at high or moderate concentrations were not the same in the six study areas. These differences in water quality reflect differences among the six study areas in the composition of the rocks and sediments that compose the aquifers, the distribution of developed land uses, the depths of wells, and other factors (Fram and Shelton, 2015).

Arsenic, boron, molybdenum, vanadium, uranium, and nitrate were all present at high or moderate concentrations in the Honey Lake Valley study area. Conditions in the Honey Lake Valley study area that contribute to elevated concentrations of trace elements in groundwater include mixing between groundwater and hydrothermal fluids; interaction between groundwater and granitic rocks of the Sierra Nevada, or sediments derived from those granitic rocks; interaction between groundwater and ancient lakebed sediments; and presence of ancient groundwater with low concentrations of dissolved oxygen (Mayo and others, 2010; Fram and Shelton, 2015). Elevated nitrate concentrations are associated with the combination of shallow wells, modern groundwater, and presence of agricultural activity.

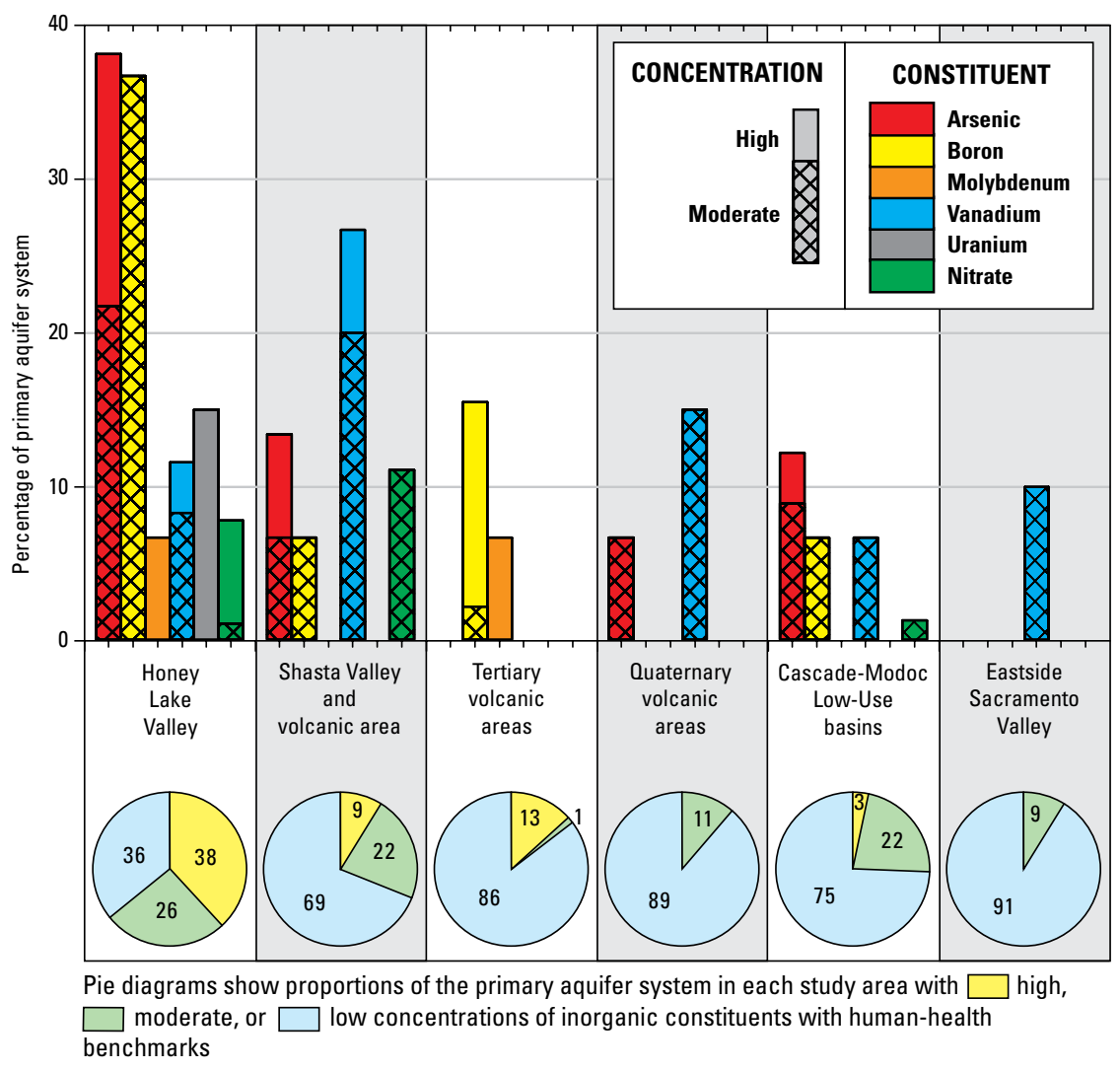

By Miranda S. Fram and Jennifer L. Shelton

\section{SELECTED REFERENCES}

California Department of Water Resources, 2003, California's groundwater: California Department of Water Resources Bulletin 118, 246 p.

Fram, M.S., and Shelton, J.L., 2015, Status and understanding of groundwater quality in the Cascade Range and Modoc Plateau study unit, 2010: California GAMA Priority Basin Project: U.S. Geological Survey Scientific Investigations Report 2014-5238, 131 p. http://pubs.usgs.gov/sir/2014/5238/.

Mayo, A.L., Henderson, R.M., Tingey, David, and Webber, William, 2010, Chemical evolution of shallow playa groundwater in response to post-pluvial isostatic rebound, Honey Lake Basin, CaliforniaNevada, USA: Hydrogeology Journal, v. 8, p. 725-747.

Shelton, J.L., Fram, M.S., and Belitz, K., 2013, Groundwater-quality data in the Cascade Range and Modoc Plateau study unit, 2010: Results from the California GAMA Program: U.S. Geological Survey Data Series 688, 124 p. http://pubs.usgs.gov/ds/688/.

\section{Priority Basin Assessments}

GAMA's Priority Basin Project (PBP) assesses water quality in that part of the aquifer system used for drinking water, primarily public supply. Water quality in the primary aquifers may differ from water quality in shallower and deeper parts of the aquifers. GAMA's Domestic Well Project assesses water quality in the shallower parts of the aquifer system. Ongoing PBP assessments are being conducted in more than 120 basins throughout California.

The PBP assessments are based on a comparison of constituent concentrations in untreated groundwater with benchmarks established for the protection of human health and for aesthetic concerns for drinking water. The PBP does not evaluate the quality of drinking water delivered to consumers.

The PBP uses two scientific approaches for assessing groundwater quality. The first approach uses a network of wells to statistically assess the status of groundwater quality. The second approach combines water quality, hydrologic, geographic, and other data to help assess the factors that affect water quality. In the CAMP study unit, data were collected by the PBP in 2010 and from the State of California database for 2008-2010. The PBP includes chemical analyses generally not available as part of regulatory compliance monitoring, including measurements at concentrations much lower than human-health benchmarks, and measurement of constituents that can be used to trace the sources and movement of groundwater.

\section{For more information}

Technical reports and hydrologic data collected for the GAMA Program may be obtained from:

\section{GAMA Project Chief}

U.S. Geological Survey

California Water Science Center

6000 J Street, Placer Hall

Sacramento, CA 95819-6129

Telephone number: (916) 278-3000

WEB: http://ca.water.usgs.gov/gama

GAMA Program Unit

State Water Resources Control Board Division of Water Quality

PO Box 2231, Sacramento, CA 95812

Telephone number: (916) 341-5779

WEB: http://www.waterboards.ca.gov/gama

ISSN 2327-6916 (print)

ISSN 2327-6932 (online)

http://dx.doi.org/10.3133/fs20143123 